\title{
Religious Tourism and Sufism in Morocco
}

\author{
Dr Driss Bouyahya
}

Moulay Ismail University Meknes, Morocco

\begin{abstract}
This study aims to uncover the relationship between Sufism and religious tourism. In other words, it attempts to shed light on the standards that make people, from different parts of the world, travel in precise times for religious reasons. In addition, this study tries to highlight the effects of that kind of travels on people's daily demeanours. Thus, this study was conducted in Fez city, Morocco, at zawya of Sidi Ahmed Tijani. The relevant data was collected qualitatively and quantitatively. The results showed that tourists who come to the zawya of Sidi Ahmed Tijani are practitioners of religious tourism since they travel from their homelands to Morocco, more precisely in Fez in order to fulfil their religious needs. Also it is shown that Tijani tourists experience a sort of cathartic process during their visits.
\end{abstract}

Keywords: Religious tourism, Sufism, Tariqa Tijaniyya, Catharsis

\section{Introduction}

Religious tourism is not a new phenomenon. Religion has long been an integral push factor for undertaking trips which is commonly referred to as the oldest non-economic travel (Jackowski \& Smith, 1992). Every year millions of pilgrims travel to major pilgrimage destinations around the world; be they ancient or modern. Religiously or spiritually motivated travel has become widespread and popularized in recent decades, and hence, it occupies a significant segment of international tourism. However, religious tourism is one of the most understudied areas in tourism (Vukonic, 1998).

The aim of this study is to contribute to the growing literature on religious tourism by reviewing concepts and practices related to pilgrimage and other forms of religious travel. By the way, in this paper, the terms (religious tourism and religious travel) are used interchangeably. In addition, the paper zeroes in on the pilgrim/tourist dichotomy and the intersections of religion and tourism from a perspective that has been little studied.

The present study examines the relationship between Sufism and religious tourism in Morocco. Sufism as a religious and spiritual tourism seems to be a worthwhile topic to be investigated in this paper, since Morocco is a Muslim country wherein many Sufis can be found regardless the brotherhoods they belong to. Moreover, in Morocco there are many religious locations such as shrines and zawyas; these are holy places where Saints are buried. They are desired destinations for some people who aim to satisfy their religious needs through worshipping, praying and donating. Since Sufism contributes to enhancing tourism in Morocco, the main purpose behind this study is to discover the link between Sufism and tourism in Morocco focusing on Tijani-Sufi order in Fez.

The objective of this study is to explore the religious tourism and its relationship with Sufism focusing on Tijani-Sufi order. It aims to provide some evidence of what makes zawiya tijaniyya a desirable destination of religious tourists and what activities they during their visits. This research seeks to address the following questions. First, does religious tourism exist in Morocco? Second, when and why do Tijani members come to Fez? Third, what do Tijani members seek in this Sufi order (Zawiya Tijaniyya)?

Some hypotheses stem from the aforementioned questions. They are outlined as follows: $1 /$ Religious tourists come to Morocco to have religious and spiritual experiences, and 2/ Tijani members practice some special rituals of their brotherhoods in order to siphon off their worries and seek spirituality when they come to Fez.

\section{Literature Review}

The review of the literature is divided into four sections; the first is an overview of what is meant by religious tourism as a general form of traveling. The second part will provide an explanation of Sufism as a form of religious activity. The third part 
is about Tijaniyya being a Sufi-order since it is the case study of this research paper. While the last section deals with the Catharsis theory by Aristotle and how it is applicable for the visitors of the zawiya Tijaniyya.

\title{
Religious tourism
}

The main step in scrutinizing spiritual tourists within the context of religious tourism must be to establish who they are and what their motivations are for embarking on their journeys. In fact, it is concepts of identity that are often at the heart of why people choose to travel. Religion is deemed as a type of archaic behavior and mode of knowledge (Halligan, 1996) ${ }^{1}$. In this respect, pilgrimage has existed as long as the first religions, and thus, pilgrims were tourists from the start and pilgrims invented tourism. In this context, Paul Kritwaczek $(2002)^{2}$ claims that pilgrimage is "a voyage of personal discovery; to explore the many guises in which the teachings of the first, and greatest, sage of ancient times lived on after his earthly life was over" (p. 27).

Broadly speaking, the relationship between Sufism and tourism could be seen ambiguous unless having a clear image about what is meant by religious tourism. There are various definitions that have been provided to explain the meaning of religious tourism. Kurmanaliyeva, Rysbekova, Duissenbayeva and Izmailov (2014) suggest that

\begin{abstract}
Religious tourism acts as a unique kind of cognitive tourism since it satisfies gnoseological interest of travelers and tourists, giving them the opportunity to observe, live through a religious cult process ceremonies and rituals, to purchase religious attributes, souvenirs (p. 959).
\end{abstract}

Thanks to this contribution, religious tourism can be defined as an act of tourism through which the travelers seek to fulfill cognitive needs related to religious interests and matters.

To illustrate more, Kurmanaliyeva et.al (2014) add "religious tourism frameworks usually presuppose visiting religious centers, functioning cultures and memorable ones, and also museums and exhibitions. Trips are made to cultural acts, holidays, and festivals taking place in a certain season"(p. 959).

In this respect, religious tourism is an act of traveling to a place in order either to accomplish a religious task, such as pilgrimage or simply to visit sacred places, attending conferences and lectures that are related to a specific religion. It may also be considered as a personal need to situate one's self in a social space in order to be recognized spiritually and religiously. Hence, religious tourism owns a kind of socio-cultural potential of influencing the motivational state of a person, which has the need of cultural and religious objects required for the spiritually ideological existence (Kurmanaliyeva et al).

Historically, pilgrimage has been depicted as a physical journey in search of truth and what is holy (Vukonic, 1996). This search for truth, enlightenment or a real experience with the holy leads people to set a trip to sacred sites that have been ritually remote from the profane space of daily life. Consequently, modern religious pilgrimages are a refuge for those who seek mysticism and spirituality and escape the modern civilization's strains. This explains the increasing numbers of tourists who are in a quest for the answers to basic inquiries of human existence, including "what is the meaning of my life?" (Olsen \& Guelke 2004; Clark 1991).

In the same vein, some scholars state that a growing number of people experience feelings of dislocation and rootlessness, mainly those immersed in Western postmodern social life (Mac Cannell, 1976; Lowenthal, 1997 cited in Olson \& Timothy, 2006). There are several motives and incentives for people to travel to a large variety of holy sites. Pilgrims and/or tourists go not only for religious and spiritual purposes and to have an experience with the sacred in the traditional sense, but also these holy sites are marked and marketed as heritage or cultural attractions to be consumed (Timothy \& Boyd, 2003). Others may target to educate their family members about their religious beliefs or for nostalgic reasons. In this respect, tourists/pilgrims also visit sacred places seeking authentic experiences, either through watching religious leaders and pilgrims perform rituals or by experiencing a "site's sense of place" or sacred atmosphere (Shackley, 2002).

\section{Pilgrim/tourist dichotomy}

\footnotetext{
${ }^{1}$ Halligan, M. (1996). Cockles of the Heart. Port Melbourne: Minera

2 Kritwaczek, P. (2002) In Search of Zarathustra. New York: Vintage Books, p. 27 
Nowadays, there is a blurring of the lines between pilgrimage and other forms of travel traditionally viewed as part of tourism. This has led to an increase in religiously and spiritually motivated travel to a wide range of sacred sites around the world. Therefore, several vistas of research have been opened into the area of religion and tourism. Nevertheless, most research and writing on the topic has focused on four distinct themes of inquiry: $1 /$ the pilgrim/tourist dichotomy, $2 /$ the characteristics and travel patterns of religious tourists, $3 /$ the economics of religious tourism and 4 / the negative impacts of tourism on religious sites and ceremonies (Olsen \& Timothy, 2006). However, this study uncovers another aspect and/or theme: spiritual purgation or catharsis in religious tourism.

The primary focus of research and debate among scholars examining religious travel has been on the tourist and the pilgrim, the main players in the relationship between religion and tourism (Cohen, 1998). Most researchers today do not distinguish between pilgrims and tourists or between pilgrimage and tourism. There is an important notion that examines pilgrimage as a form of tourism because a 'pilgrim' is deemed as a tourist (religious tourist) who is motivated by spiritual or religious factors. Therefore, pilgrimage is typically accepted as a form of tourism (Fleischer, 2000), for it exhibits most of the same characteristics in terms of travel patterns and the use of transportation, services and infrastructures.

On the contrary, the opposing perspective refutes the fact that pilgrims are tourists. In this vein, travelers who are motivated by profound spiritual or religious impetus (i.e. pilgrims) are seen as somehow different from those motivated by pleasure, education, curiosity, altruism, and relaxation. Mainly, it is various religious organizations that hold to this point of view.

Some other researchers, like Smith (1992), state that rather than viewing pilgrims and tourists as two distinct groups, it is better to place them both on a continuum with pilgrims at one end and tourist at the other. Similarly, while tourists may appear different from pilgrims, they can be moved by religious emotions just as well as pilgrims (Eade, 1992). In other words, people can switch from being a pilgrim to a tourist and vice versa without the individual being aware of the change from one to the other.

In a nutshell, the difficulty of distinguishing between pilgrims and other tourists can be seen in the official statistics of many countries, where existing figures tend to combine pilgrimage and religious tourism with cultural or heritage tourism (Russell, 1999). To avoid any controversy and ambiguity, this study will use both pilgrim and religious tourist interchangeably. This way, we will adopt the "golden mean" in dealing with the pilgrim/tourist dichotomy.

\section{Sufism}

The concept of Sufism has been the concern of many scholars and researchers; that is, many definitions have been postulated to explain what Sufism is, and a set of them are cited

in Bouasria (2015). Sufism has been defined as a vehicle for the spread of Islam (Trimingham 1971), an ascetic piety (Ling 1994), an organizational basis of resistance against colonialism (Evans-Pritchard 1949), a mean of psychiatric treatment (Crapanzano 1973), and a force of reform (Gilsenan 1973). The organizational structures that follow Sufism are called tariqa, meaning "way", "order" or "path" (p.20).

According to Encyclopedia Britanica, Sufism is the "mystical Islamic belief or practice in which Muslims seek to find the truth of divine love and knowledge through direct personal experience of God"1. In this regard, Sufism consists of a variety of mystical paths which are designed to ascertain the nature of humanity and of God and to facilitate the experience of the presence of divine love and wisdom on earth. The substance of Sufism is truth and the selfless experiencing and actualization of the truth. Sufism is a school for the actualization of divine ethics. It encompasses an enlightened inner being, not intellectual proof; revelation and witnessing, not logic. In other words, divine ethics refer to ethics that transcend mere social convention, a way of being that is the actualization of the attributes of God.

Many scholars argue that Sufism is a branch of Islam. Sufism is a spiritual discipline of Islam that is a vehicle for many Sufis to be close to their God spiritually in order to get the absolute knowledge and then to become a divine and a wise person Saladdin (2008). In the same vein, he adds that

The word truth, or haqiqa- Haq, is a key word in the philosophy of

\footnotetext{
${ }^{1}$ www.encyclopediabritanica.org. Retrieved on June 30th, 2016
} 
Sufism, as I will show later. For a Sufi, there is one truth which is

the only God, and there is one God who is the only Truth. Sufism

is simply a path to that goal, to become one with Truth or the Unity

of Being. At that point the Sufi becomes God, which is the sacred

goal for a Sufi. (p.2)

Saladdin's definition of Sufism is more of a philosophical stance. In other words, the path to the absolute truth refers to God. This absolute truth, for him, does enable the Sufi to become a Godlike. However, this claim might be acknowledged by Muslims since it literally means to be a partner with God which is a terrible guilt in Islam that is referred to as 'Shirk' (heresy).

As an attempt to defend his claim, Saladdin argues that "the Sufi's challenge is to overcome the self in order to let God be, i.e.to become God" (p. 3). In this respect, the explanation of the goal which is considered sacred by Sufis 'to become God' has been altered to the total self-denial; it means nothing is important but God who is the only truth that remains. In this sense, there is no claim of partnership with God; therefore, there is no sin committed in term of Islam.

Moreover, Nasr (1970) argues that "Sufism is a divine trust originating in the mercy of God and placed within Islam [...] Sufism gives to man the means to know himself and thus to know God" (p.2). This definition seems to be similar to the previous scholar's contribution. In other words, he defines a Sufi as a Muslim who devotes him/her self and seeks for pity from God. Also he emphasizes that Sufism is a powerful medium that leads to divine knowledge through knowing the inner self which is the center of the existence. Bouasria argues that it is "the mystical and esoteric branch of Islam" (p.20). What makes it mystical and esoteric is that it addresses the spiritual side of Muslims in order to get the internal religious nourishment. In fact, this remains the ultimate goal of Sufism.

Furthermore, Sufism in Morocco, is a bless and absolute happiness and an experience that is offered to the worshippers in order to provide them with a spiritual rapture. It is also a reforming act to prevent extremism and all its negative and tragic consequences (Gurraoui, 2016). Similarly, Chtatou (2016) states "Sufis are focused on their search for a way inside themselves that will lead them to God. They believe that the path to Him can be found through mediation and purification". (p.19). In other words, Sufi people focus mostly on the inner side of the self which is the center of being and the only way towards God. They mediate and attempt to purify themselves in order to reach that goal.

It is argued that Sufism is a set of spiritual and religious practices that a Sufi person does in order to purify one's soul and to get a divine knowledge from God. According to Bouasria (ibid), a Sufi is the practice of Sufism; he/she is someone who has the will to purify his/her soul under the guidance of a teacher who is mostly called a master, or sheikh. Along with Nasr, Sufism's main objective is to guide the man to be separated from the world of materials to the world of spirit in which the inside is more important than the outside. Moreover, a Sufi is somebody who always travels looking for mystical and divine knowledge by attending Sufis philosophers' lectures and mediating (Saladdin, 2008).

Although Sufism is an allusive concept constantly in flux, the aforementioned definitions agree that Sufism, being a branch of Islam, is a way of worshipping God, purifying the soul, and seeking wisdom, the divine knowledge and the absolute truth. Yet, this way may differ from one group to another according to the brotherhood a Sufi belongs to and the path or order adopted. A path or order in Sufi-culture is called tariqa; it is a well-structured way of Sufism that differs from one brotherhood to another, such as "Boutchichiya", "Darqawiya", "Wahhabiya", "Tijanniya" and "Kettaniyya".

\section{Tijani-Sufi order}

Since this research paper is targeting the members of Tijani-order, it is useful to provide an explanation of what Tijaniyya as a Sufi way or Tariqa is and how it has evolved.When speaking about Tariqa Tijaniya, it is worth mentioning the beautifully decorated zawiya of Sidi Ahmad Tijani in Fez. It/he is widely visited from all over the Arab world as well as Africa (Abeddour, 2011). What can be interpreted from Abeddour's input is that the decoration of the zawiya Tijaniyya is one of the factors that make it largely visited by people from many parts of the world especially from the Arab world and 
Africa. However, many reasons can illustrate the visit of Sufis to zawya Tijaniya, such as attending ceremonies, chanting 'Dikr' and networking.

Skiredj (2001) defines, "Tijaniya way is a spiritual membership, which consists of praises and thanks to Allah. It is simple and does not require from the individual to lead a strict monastic life, to spend his whole time in fast and prayer, to avoid women or go to countercurrent of the natural customs of the life" (p. 35). Skiredj's definition of Tijaniya seems to be an attempt to deny some assumptions about Sufism and its practitioners who most of the times exaggerate in their worshipping as they free themselves from the materialist world and start their devotion to God. Tijaniya order, therefore, does not require a sacrifice act per se.

It would be unfair to talk about Tijani path without providing an overview about the founder and the master of Tijaniyya order who is Sheikh Sidi Ahmed Tijani. According to Skiredj, Sidi Ahmed Ben M'hamed Ben El Mokhtar Tijani was born in 1150 of the Hegira at Ain Madi (Algeria) and he died in 1230 of the Hegira in Fez (Morocco). He studied the Quran and religious sciences with the professor Muhamad Ben Hammou Tijani; he was specialized in Sufism through various professors.

Among Sufi Sheikhs, Sidi Ahmed Tijani is considered the most worth to be the intermediary between the disciple and God. He said as cited in Skiredj (2011) "No Sufi Sheikh could claim that he did you some favors. I am your real intermediary and provider. Therefore, abandon all what you did take as Sufi ways" (p. 20) (Translation mine). In other words, to be a Tijani member is to take Sheikh Sidi Ahmed Tijani as the one and the only guide or master and to abandon the others. Moreover, Skiredj states "visiting other Sufi saints is also forbidden in Tariqa tijaniyya [...] we should love, venerate, and respect them but not to visit them" (p.24) (Translation mine). One of the conditions of Tijaniyya is to never visit a tomb or zawiya of any Sufi Sheikh except Sidi Ahmed Tijani. They should be respected, venerated, and loved because they are religiously knowledgeable and wise.

Besides, Skiredj (2001) provides other practices that the Tijani disciples should follow. First, the 'wird' has to be recited individually in the morning or the evening. That is, twice a day. It consists of the recitation of 'Astaghfirou Allah' 100 times; it means to ask Allah forgiveness. Also, 'Salat el Fatihi' 100 times; it is a special version of the prayer on the prophet. Second, 'al-wadzifa' it is done collectively in the zawiya. It entails the asking for God's forgiveness 30 times, 'Salat el F Fatihi' 50 times, 'La ilaha illa Allah' 50 times, and the 'Jawharat Al Kamal' or the pearl of perfection 12 times. The 'al-wadzifa' is done in the zawiya in every 24 hours so that Tijani members can get involved. Third, the 'Haylala'; that is, to say "there is no God but Allah". It has to be recited collectively every Friday, between the prayers of El Assr and El Maghghreb, by the Tijani members in the zawiya. It can be also recited individually from 1000 to 1600 times. Hence, the prayers on the Prophet are essential and of paramount importance in Tijani order.

\section{Theoretical framework}

This section tackles a theoretical framework which is significant in this paper to provide an explanation of the topic investigated. A theory, moreover, adds value to the study and makes it worth.

\section{Catharsis theory}

The Catharsis theory by Aristotle who by which he explained the strong impact of the tragic character portrayed in drama or poetry on the audience's state of minds.

"Purging the spirit of morbid and base ideas or emotions by witnessing the playing out of such emotions or ideas on the stage" (Aristotle, 2001. p. 1458). According to Aristotle, Catharsis refers to the experience of cleansing and healing of the spectators' emotions while and after watching a tragedy, this experience has a positive influence on their state of minds. Although this research paper is far from these subjects such as drama, poetry and so on, catharsis theory seems to be applicable in Sufism as an act of purifying and cleansing the soul of its practitioners. Moreover, this theory is of a great assistance in this research paper because it will be a crucial tool to examine the effects of the Sufi rituals done by Tijani members during their visit to the zawya Tijaniya on their emotions and psyche.

In the same vein, Scheff (2001) defines "Catharsis is a process of emotional discharge which brings relief to emotional tension" (p.47). In this respect, catharsis is as a process in which the person releases and gets rid of all emotional tension and pressure. In fact, it is also a theory that siphons off one's worries, tension and pressure 
Furthermore, Powell (2007) defines catharsis as a concept derived from the Greek word that has been translated as 'cleansing' or 'purification'. He adds that " Catharsis has been recognized as a healing, cleansing, and transforming experience through history, and has been used in cultural healing practices, literature, drama, religion, medicine, and psychology" (p.1) Similarly, catharsis is applied not only in drama, poetry, and music as Aristotle claims, but it also used in many other fields, religious practices and experiences. Most of these definitions emphasize two essential components of catharsis: The emotional aspect (strong emotional expression and processing) and the cognitive aspect of catharsis (insight, new realization, and the unconscious becoming consciousness) that culminates in a "positive change". Powell's contribution to the definitions of catharsis is vital because he acknowledges that Catharsis is more than a scene side effect on the spectator's emotions; rather it is a positive change on a person's spirit and mind during and after experiencing a cathartic activity. In other words, the spectators acquire more awareness and consciousness of both the internal and the external side of their life. The visit of Tijani members to zawya Tijaniyya and the rituals they perform may also be considered as cathartic since they come with their strong will to realize purgation and the inner cleansing of their souls. Consequently, the rituals are often considered as part of a person's healing from the devastating effect of guilt (Powell, 2007).

\section{Methodology issues}

This research paper examines the relationship between Tijani Sufi order and religious tourism in Morocco. It explores how this Sufi brotherhood could be a form of catharsis and purgation for some Tijani tourists. In this respect, I opt for purposive sampling. This type of sampling seems to be fruitful while collecting and analyzing data. Therefore the target population of this research are the members of Tijaniyya precisely the tourists who come to Fez to visit zawya Tijaniyya where the master Sidi Ahmed Tijani is buried and where they practise religious tourism and may have cathartic experiences.

In academic contexts, a research has to be given credibility and validity. Therefore, in order to achieve this purpose in this study, the suitable design that would yield reliable results is the qualitative approach. However, it is significant to explain what is denoted by credibility, validity, and reliability in a qualitative research. In this respect; Golafshani (2003) states "the credibility of a qualitative research depends on the ability and efforts of the researcher" (p.4). In this respect, reliability and validity are conceptualized as trustworthiness, rigor, and quality in qualitative paradigm.

The focus in this research is on meanings transmitted by the way my interviewees respond through to my questions. In order to explain relationships and to explore individual experiences rather than the numbers and statistics that quantitative approach seeks for, the appropriate design to be used in this study is qualitative. According to Golafshani (2003), a qualitative research adopts a naturalistic approach and aims to understand phenomena in a specific setting that it related to the context of the research.

Qualitative data are rich and worth in this study for many reasons, such as the freedom to express themselves through the language they prefer; English, French, or Arabic. First, the major quality which characterizes the interview is the interaction between the researcher and the respondents. This enriches the research by unexpected data that would make the researcher oriented to new perspectives.

The research instruments in qualitative study and the instruments that used to collect data are diverse; there are interviews, focus group, and discussion group. However, I opt to use interviews. The interviews allow respondents to freely present their life situation in their own words, and open for a close personal interaction between the researchers and their subjects (Kvale, 2006).

Second, semi-structured interviews are sometimes done in an informal, conversational, or 'soft' manner that allows the participants to explore issues they feel are important (Longhurst, 2010). This format of interviews is probably the most commonly used in qualitative method. Third, the interaction between the participant and the reporter will be presented; thus, this method provides the interviewer an opportunity to learn more about the experience of the interviewee and to develop rapport with him or her to be able to ask follow up probing questions based on their responses.

\section{Findings and discussion}

This section is divided into two parts. The first deals with the findings. That is, it presents the data collected in the practical part through interviews, and then it analyzes them. The second deals with the discussion, it revises the research questions, 
the research hypotheses and compares them with the findings according to the theoretical framework dealt with in this study.

The practical part of this research is conducted on Fridays, May 13th, 20th and 27th, 2016, in the zawya of Sidi Ahmed Tijani, Fez. I have chosen to go on Fridays because many Tijani members come those days to the zawya, and it is easier to collect data from different individuals, that is, different points of view. I have interviewed 9 tourists, out of which four are males while five are females. The participants who were interviewed for this study are aged between 30 and 50 years old. This part covers the practices that Tijani tourists do in the zawya and the reasons behind their visits, and it scrutinizes their cathartic experience during and after visiting the zawya. Subsequently, it is necessary to provide a vivid background about the respondents who participated in this study.

\begin{tabular}{|l|l|l|l|l|}
\hline Item & Name & Age & Education & Country \\
\hline 1 & Khadija & 30 & Islamic Education & Belgium \\
\hline 2 & Fatim & 42 & Islamic Education & Senegal \\
\hline 3 & Natasha & 39 & Islamic Education & Senegal \\
\hline 4 & Mariam & 45 & Islamic Education & Mauritania \\
\hline 5 & Aisha & 34 & Islamic Education & Nigeria \\
\hline 6 & Mouhammado & 47 & Islamic Education & Senegal \\
\hline 7 & Ibrahim & 34 & Islamic Education & Nigeria \\
\hline 8 & Tariq & 32 & Islamic Education & Mauritania \\
\hline 9 & Hassan & 34 & Islamic Education & Egypt \\
\hline
\end{tabular}

According to the chart above, it is worth mentioning that the correspondents do share many features. First, they are all foreigners; it proves that they are willing to travel in order to fulfill their religious needs or interests. Here they are pilgrims rather than tourists. Second, the fact that the participants come from different countries demonstrates that Tijani path is popular worldwide. This sample is a real diaspora. Third, all the participants have studied Islamic education; this explains that they have background knowledge about Islam. Therefore, all of the participants mentioned above can be considered as intellectual pilgrims who seek both cultural and spiritual catharsis.

Based on the various nationalities of the visitors to zawya Sidi Ahmed Tijani, this research attempts to discover the visitors' practices during their visit, reasons behind the visit, and to evaluate whether there is a sort of release and catharsis in the process. It is necessary to mention that the questions I raised in these interviews were prepared before, but there are some questions I added while conducting the interviews. This study is based on a sample of 9 Tijani tourists/pilgrims who have provided interesting answers.

The first question was about the frequency of their visits. The majority of the respondents come occasionally; they come in Sha'ban, which is the month before Ramadan and on the birthday of the prophet. Also, they come in the period of pilgrimage before taking the direction to Mecca. Then I wondered why in Sha'ban and not in Ramadan which is the holy month for Muslims all over the world. The answers to this question were various. Many of the participants including Tariq (32 years old), Hassan (34 years old), and Mariyam (45 years old) answered that it is the right time to come and visit the zawya and take 'al-Baraka' (Benediction/Divine grace) of their sheikh Sidi Ahmed Tijani in order to start Ramadan with a fully pure soul.

Moreover, one of the reasons according to Mouhammado (47 years old), is the issue of 'al-Omra'; he explained that "It is the perfect time for me to be here in the zawya because afterward I will pay a visit to Mecca". Ibrahim (34 years old) agreed with Mouhammado, he also considers his visit to Sidi Ahmed Tijani as the first path of his al-Omra to Mecca. However, Mariam (45 years old) acknowledges "I do not have a fixed schedule to come and visit the zawya, I consider it as my second home; I come whenever I feel that I have to. I am here now, and after a month or less you will find me here again".

Natasha (39 years old) illustrates that "Ramadan requires us to be home with our families, that is why I prefer to come in Sha'ban", Fatim (42 years old) agrees with Natasha's answer, and states that "I am a mother, I have many duties towards 
my family so I cannot come here in Ramadan when my presence as a mother is necessary". Besides, Khadija (30 years old) said "it is my second visit to Sidi Ahmed Tijani, the first time I came was last year in Sha'ban too, I like the atmosphere here and I am planning to come more often Insha'Allah" while Aisha (34 years old) states "I think it is the right time to come to Sidi Ahmed Tijani. First, because to be ready spiritually for Ramadan. Second, to meet my sisters in Islam since most of them come in this month too".

The following question was about the rituals and practices that the Tijani pilgrims do in Sidi Ahmed Tijani. Most respondents replied that they pray, remember God through 'Dhiker', and ask for His forgiveness, sometimes together and sometimes individually. They also recite Quran, sing religious hymns mostly in group and visit the tomb of Sidi Ahmed Tijani.

One of the respondents' answers was to rectify a terminology controversy. In other words, Khadija claims "by the way 'rituals' is not the right term, we do not have rituals, we worship. You may say this word when you are addressing many other memberships but not Tijaniyya. What we do in the zawya is exactly what we do in our homes, and it is exactly what everybody who claims to be Muslim has to do. Many people believe that Tijaniyya has some practices that are against Islamic religion but they are wrong. They do not know about our brotherhood, they should learn about it then judge it". According to her intonation while speaking, it seemed that she was defending her point of view and her identity.

Among the questions I have raised was: Who is Sidi Ahmed Tijani for you? The participants' answers to this question were almost the same; all of them have a deep respect towards this saint, but each of them expresses that respect in a particular way that does differ from one to another. According to Khadija, Sidi Ahmed Tijani is a guide to Tijani members. He has more knowledge and wisdom than they have. As his saying: "if you want to follow me, you should follow the Sharia", that is, Tariqa Tijaniyya is only based on Quran and Sunnah. Similarly, Aisha's respond was "Sidi Ahmed Tijani is our father; he is the second and the spiritual father of all Tijani members". Mouhammado, on the other hand, certifies that "He is a lay person like you and me but he is versed in Sharia and Islam. In addition, Hassan argued that Sidi Ahmed Tijani is not a prophet as many people claim; rather, he is the master of Tijani members that guides them and provides them with the right way of worshipping. While the answer of Natasha was that "we, as members of Tariqa Tijaniyya, consider Sidi Ahmed Tijani as an idol that guides us towards the straight path. Many people who do not belong to this brotherhood claim that our visit to Sidi Ahmed Tijani is to ask him for his benediction instead of asking our God. This is totally wrong; we love, we respect Sidi Ahmed Tijani because of his wisdom and knowledge but we do not worship anyone but Allah".

The following question was: What does attract you when you come to Fez in general and to zawya of Sidi Ahmed Tijani in particular? The answers to this question seem to be identical among the participants. They have agreed that it is not a matter of attraction; rather it is about the faith. Mariam said that "it is the faith that makes me come here frequently". Khadija also kept repeating "c'est la foi, c'est la foi" meaning it is the 'faith'. Even the interview was conducted in English; she said so in French to stress her faith in Islam and Zawiyya.

The most important point in this study is to scrutinize whether the participant experience a sort of cathartic feeling during and after their visit to Sidi Ahmed Tijani. For this purpose, the last question I raised was: How do you feel during and after your visit? Do you feel yourself released when you come to the zawya?

Ibrahim said "absolutely yes", and then he added "here is the place that I love the most, I love our Sheikh Sidi Ahmed Tijani and I am thrilled to be in here". Aisha supports Brahim's idea, "it is such a peaceful place, where one feels released from daily stains". Moreover, Khadija responded while smiling "I feel so happy and pleased to be here. In fact, it is the best place to get rid of stress we live in our homelands". Also, Mouhamadou said something very interesting; that is, there is always a big difference of him before he came to visit the zawya and after his visit, he emphasized that his soul becomes pure and clean. In addition, Fatim's answer was confirming that she feels better when she is in zawiya. She said that "it is the case of all believers from any part of the world; the more you are closer to your God, the more released and content you become. This is what happens to me when I am here; I come to have that feeling". Thus, all the participants of the interview do confirm that the reason behind their visit is to release, purify their souls, and to feel content of themselves.

Sufism, as explained by the Sufi pilgrims, is a spiritual journey to discovering one's inner self which leads to knowing God. In other words, Sufism allows for the expression of spirituality; it is also a process that makes one learn how to follow the very deep path inside one's self. While visiting Zawiyya Tijaniyya, these Sufi pilgrims' goal is to get closer to God in order to embrace his presence in their daily life. 


\section{Discussion}

Based on the findings of this research, Tijani members frequently visit the zawya of Sidi Ahmed Tijani for religious and spiritual catharsis; they come in order to free their minds from anything and focus on worshipping God. They also come to visit the tomb of Sidi Ahmed Tijani, who is considered as a spiritual father, guide, and teacher. According to the Tijani Sufi pilgrims interviewed, they believe that Sidi Ahmed Tijani is the one who preached Islam in Africa the reason why he is widely visited by Africans. The pilgrims' visit to Sidi Ahmed Tijani shrine epitomizes their pride and honor to pertain to this Sufi order. Besides, some of the interviewees consider the zawya as the first path while they are directing Mecca for alOmra. These data answered the first research question - Does religious tourism exist in Morocco? - The answer is yes, it does. Moreover, these data confirmed the validity of the first research hypothesis that tells: Religious tourists come to Morocco for religious and spiritual experiences. Tijani members pray, remember God, read verses of the Quran, and recite religious hymns. Also, they visit Sidi Ahmed Tijani's tomb. Moreover, some of them attend lectures and conferences when they occur. All these practices are parts of a spiritual and religious process.

Concerning the second research question: When and why do Tijani members come to Fez? According to what has been mentioned in the review of literature about Tijani-Sufi order and the correspondents' answers, the zawiya is always opened to everybody so they can come whenever they want to. However, the majority of the foreign Tijani members prefer to come in occasions, such as Sha'ban ${ }^{1}$ and the prophet's birthday commemoration (Miloud).

The second research hypothesis claims that Sufis use incentives and marketing to attract more tourists. This hypothesis seems to be weak while talking about Tariqa Tijaniyya because, according to the interviewees' responses, their visits have nothing to do with attraction rather it is an act to express their faith to their religion and to celebrate their sense of belonging to Tijani brotherhood. In addition, their visits are to satisfy their emotional and spirtual needs, such as to release, and to purify their soul. This emotional satisfaction and purgation is the so called "catharsis experience".

I opt for catharsis theory because it is of great help to account for, to describe and to explain the audience's emotional change during and after watching dramatic scenes especially tragic ones. However, the correspondents' answers show that this catharsis process is also experienced and applied by Tijani members during and after their visit to zawiya Tijaniyya

The third hypothesis in this research states that Tijani members practice some special rituals to the Tijaniyya brotherhood when they come to Fez. Indeed, they have few special practices such as 'wird', 'al- wadzifa', and 'Haylala', coral religious hymns recitation, distributing milk and other meals occasionally as a way to commemorate the birth of the prophet. Nonetheless, there are some other practices that are common among all Muslims, such as praying and reading. Even though, they refused to refer to these practices as rituals because according to a Belgium tourist, the term "ritual" is very offensive to their brotherhood, but it is rather a 'practice'.

Sufism in Morocco, mainly Tijaniyya brotherhood, is a way to purifying the pilgrims' heart from bad manners. It aims at $1 /$ seeking the pleasure, $2 /$ love and peace with one's self, and 3 / harmony with all creations (mankind, animals and nature). Religious tourists and/or pilgrims come to Morocco to live and experience the process of purification and an inner trip through a variety of practices, such as visiting Zawiyas and shrines, reciting and singing religious hymns. Thus, Sufi tourism in Morocco has become a desirable destination par excellence to many tourists from different corners of the globe.

\section{Conclusion}

This study has attempted to explore the relationship between Sufism and religious tourism in Morocco. It aims to find out whether the religious tourism exists in Morocco. It also seeks to discover when and why Tijani members come to zawiya Sidi Ahmed Tijani and what they do during their visit. From the discussion above, it is clear that religious tourism is a kind of tourism that refers to the act of leaving one's homeland to accomplish religious tasks such as pilgrimage especially in Mecca, spreading religion that is referred to as 'da'wa' (proselytizing) in Islam; this kind of traveling is well known in Pakistan

\footnotetext{
${ }^{1}$ It is the month before Ramadan which is one of the sacred months in the Muslim calendar where Muslims fast for the whole month from dawn to dusk. 
and the surrounding countries. Also attending lectures and conferences about religion overseas are deemed types of religious tourism.

According to data description and analysis, many people who belong to Tijani-Sufi order come from different countries to Morocco in order to visit Sidi Ahmed Tijani's tomb and to perform other religious practices. This is a tangible proof that Sufism is a form of religious tourism in Morocco more precisely in Fez. Furthermore, when Tijani Sufi tourists come to Fez, stay in the zawiya, meet other members, visit Sidi Ahmed Tijani's tomb, read Quran, and pray, they are in fact experiencing a cathartic process that enables them to feel released, content and emotionally satisfied. Religious tourism is one of the most flourishing aspects of tourism that has been well-taken care of in Morocco. Hence, the country has diversified the forms of tourism to meet the different needs and wants of the tourists. Importantly, Sufism in Morocco distinguishes it from other countries because it is the most desired destination for tourists who seek spiritual purgation and tranquility.

\section{References}

[1] Abeddour, Y. (2011). Sufi Tourism in Morocco: The Impact of Sufism on Tourism. Morocco World News. http://www.moroccoworldnews.com/2011/08/7467/sufi-tourism-in-morocco-the-impact-of-sufism-on-tourism. Retrieved on June 20th, 2016

[2] Aristotle. (2001). The Basic Works of Aristotle. McKeon, R. (Ed). New York: Modern Library.In Powell, E. (2007). Catharsis in Psychology and Beyond: A Historical Overview: The primal psychotherapy.

[3] Bouasria, A. (2015). Sufism and Politics in Morocco: Activism and Dissent. New York: Routledge.

[4] Clark, N. (1991). "Developments in Human Geography: niches for a Christian contribution", Area 23(4): 339-345

[5] Cohen, E. (1992). 'Pilgrimage \& Tourism: Convergence \& Divergence'. In Morinis, A. (1992). Sacred Journeys: The Anthropology of Pilgrimage. West Port: green Wood Press

[6] Crapanzano, V. (1973). The Hamadsha: A Study in Moroccan Ethno psychiatry: University of California Press, Berkeley, Los Angeles, and London. In Bouasria, A. (2015) (Eds). Sufism and Politics in Morocco: Activism and Dissent. New York: Routledge

[7] Cresswell, J. W. (2003). Research design qualitative, quantitative, and mixed methods approaches. Thousand Oasks, California: Sage Publication Inc.

[8] Eade, J. (1992). Pilgrimage \& Tourism at Lourdes, France. Paris: Pergamon

[9] Evans-Pritchard, E. E., \& Firth, R. (1949). 179. Anthropology and Colonial Affairs. Man, 49, 137-138. Cited in Bouasria, A. (2015). Sufism and Politics in Morocco: Activism and Dissent. New York: Routledge.

[10] Fleischer, A. (2000). The tourist behind the pilgrim in the holy land, Hospitality management 19: 311-326

[11] Gilsenan, M. (1973). Saint and Sufi in modern Egypt: An essay in the sociology of religion. Oxford: Clarendon Press. Cited in: Bouasria, A. (2015). Sufism and Politics in Morocco: Activism and Dissent. New York: Routledge.

[12] Golafshani, N. (2003). Understanding reliability and validity in qualitative research. Tronto, Ontario, Canada: University of Tronto.

[13] Guerraoui, S. (2016). Sufism in Morocco 'a powerful weapon' against extremism. Casablanca: The Arab Weekly.

[14] http://www.thearabweekly.com/?id=4504. Retrieved on June 1st, 2016.

[15] Jackowski, A \& Smith, VL. (1992). "Polish Pilgrim-tourists", Annals of Tourism Research

[16] 19: 92- 106

[17] Kurmanaliyeva \& Rysbekova, Sh \& Duissenbayeva, A \& Izmailov, I. (2014). Religouis Tourism as a Sociocultural Phenomenon of the Present "The Unique Sense Today is a Universal Value Tomorrow. This is the way Religions are Created and Values are Made": $3^{\text {rd }}$ Cyprus International Conference on Educational Research. Lefkosa: North Cyprus.

[18] http://www.sciencedirect.com/science/article/pii/S1877042814044620. Retrieved on May 21st, 2016

[19] Kvale, S. (2006). Dominance through interviews and dialogues. University of Aarhus, Denmark: Sage Publication. 
[20] Ling, M. (1994). A Sufi Saint of the Twentieth Century: Shaikh Ahmad al-'Alawi: His Spiritual Heritage. The Islamic Texts Society.In (Eds), Bouasria, A. (2015). Sufism and Politics in Morocco: Activism and Dissent. New York: Routledge.

[21] Longhurst, R. (2010). Semi-Structured Interviews and Focus Groups (2nd edition). In Clifford, N (Ed). Kings College London, UK: Sage publications.

[22] Mac Cannell, D. (1976). The Tourist: A New Theory of the Leisure Class. Berkely: University of California Press

[23] Nasr, H. (1970). The Influence of Sufism on Traditional Persian Music. Tehran: The Magazine Salash \& The Journal Ma'ârif-iislami (Islamic Studies). Translated by Chittick, W. (1972).

[24] Olsen, D. H. \& Guelke, J. K. (2004). "Spatial transgression and the BYU Jerusalem Center Controversy", Professional Geography 56(4): 503-515

[25] Olsen, D. H. \& Timothy, D. J. (2006). Tourism, Religion and Spiritual Journeys. New York: Routledge

[26] Powell, E. (2007). Catharsis in Psychology and Beyond: A Historical Overview: The primal psychotherapy. http://primal-page.com/cathar.htm. Retrieved on May 16th, 2016.

[27] Russell, A. (1999). "Religious travel in the New Millennium", Travel \& Tourism Analyst 5: 39-68

[28] Saladin, A. (2008). What is Sufism? Canada: Brock University: Forum Philosophicum.

[29] Scheff, T.J. (2001). Catharsis in Healing, Ritual, and Drama. Berkeley, Los Angeles: University of California Press.

[30] Shackley, M. (2001). Managing Sacred Sites: Service Provision and visitor Experience. London: Continuum

[31] Skiredj, A. B. Ab (2001). The Guide of the Tijani Disciple. Rabat: Imprimerie Yadip.

[32] -.--(2011). "Nourou As- Siraj" La lumière de la lampe (Guide pratique du Moqadem Tidjani). Rabat: Imprimerie Yadip.

[33] Smith, V.L. (1992). ' Introduction: The Quest in Guest'. Annals of Tourism research 19(1): 1-17

[34] Timothy, D. \& Boyd, S. (2003). Heritage Tourism. New York: Pearson Education.

[35] Trimingham, J. S. (1971). The Sufi Orders in Islam. New York: Oxford University. In Eds, Bouasria, A. (2015). Sufism and Politics in Morocco: Activism and Dissent. New York: Routledge. 